\title{
GASTRIC AND COLORECTAL CANCER MORTALITY IN AN URBAN AND INDUSTRIALIZED AREA OF BRAZIL
}

\author{
Marcilia de Araujo Medrado-Faria, José Wilson Rodrigues de Almeida and Dirce \\ Maria Trevisan Zanetta
}

RHCFAP/3035

MEDRADO-FARIA M de A et al. - Gastric and colorectal cancer mortality in an urban and industrialized area of Brazil. Rev. Hosp. Clín. Fac. Med. S. Paulo 56(2):47-52, 2001.

Purpose: To study the gastric and colorectal cancer mortalities and their relation to the urban-industrialization in Baixada Santista, located in the southeastern region of Brazil.

Methods: Selected from the registries of the State System of Data Analysis Foundation (SEADE) were 1105 deaths due to gastric cancer (ICD 153-154) and 690 due to colorectal cancer (ICD 151) that occurred from 1980 to 1993 in males, above 10 years of age, residing in Baixada Santista. For each of these types of cancer, the standardized mortality rates, age-adjusted by world population in the 1960s, for 4 industrialized and 4 non-industrialized urban communities in that region were calculated. The ratios among those rates were calculated in order to compare the mortality in the periods 1980-93, 1980-1986, and 1987-1993.

Results: Standardized mortality rates for colorectal cancer were significantly higher in industrialized area, with ratios of 1.6 [95\% CI 1.22 - 2.29], 1.6 [95\% CI 1.2 - 2.0], and 1.6 [95\% CI $1.3-2.0$ ] in the periods 1980-86, 1987-1993 and 1980-93, respectively. Gastric cancer did not show any statistical difference between the industrialized and non-industrialized areas, but there was a significant decrease in BS from the period 1980-1986 to 1987-1993.

Conclusions: The significant elevation of colorectal cancer mortality in the industrialized area could be related to exposure to numerous carcinogens such as aromatic hydrocarbon, organic-chloride, metals, and industrial-port dust present in the region. Alternatively, the non-significant difference in gastric cancer between industrialized and non-industrialized areas and significant decrease in the last few years could be predominately reflecting the advances in the quality of life in urban areas. These results require further case-control studies that could help with the analysis of the associations among cancer and environmental factors (occupational, urban-industrial, habit, and life condition) and genetic susceptibility.

DESCRIPTORS: Cancer mortality. Cancer epidemiology. Stomach cancer. Colorectal cancer.

Parkin in $1993^{1}$, analyzing estimates for the world incidence of cancer for males up to the year 1985, observed that gastric cancer (GC) was in second place $(25.4 / 100,000)$ and colorectal cancer (CRC) in third place (17.8/100,000). When the incidences among developed and developing countries were considered, he observed GC in first place in the former, including the tropical region of South America in which Brazil is situated, while CRC ranked second in all developed countries.
In Brazil, the morbidity and mortality due to GC has risen, reaching first place among all kinds of cancer in the 1970s and 1980s, except in the more developed regions such as the south and southeast. In contrast, the mortality and incidence of CRC are not as high, and this type of cancer is not ranked among the first five ${ }^{2,3}$.

From the Discipline of Labor and Social Medicine of the Oscar Freire Institute, Faculty of Medicine, University of São Paulo.
Although the excessive mortality of GC and CRC has usually been associated with lifestyle in urban and industrialized areas, several authors have shown a relationship between these kinds of cancer and exposure to occupational carcinogenic agents ${ }^{4-8}$. Baixada Santista is an important port and industrial center in the state of São Paulo (SP), Brazil, where industrial wastes with carcinogenic substances have been found ${ }^{9,10}$, and it has the highest general mortality by cancer in $\mathrm{SP}^{3}$. Therefore, this ecologic study, part of 
the project "Cancer and Work", analyzes the GC and $\mathrm{CRC}$ mortalities in that region.

\section{MATERIALS AND METHODS}

Baixada Santista is an urban and resort area that has an important industrial and port complex on the southeast coast of Brazil, close to the metropolitan region of São Paulo, situated between the ocean and the coastal mountain range. In 1994 there were 1.3 million inhabitants-86.3\% living in the industrial-port area (IP), made up of the following municipalities: Cubatão, Santos, São Vicente, and Guarujá and $13.6 \%$ in the other 4 municipalities, outside the industrialized area: Praia Grande, Mongaguá, Itanhaém, and Peruíbe (NIP) ${ }^{11}$.

Data obtained from the Social Information Annual List (RAIS) ${ }^{\mathrm{b}}$, edited by the Labor Ministry, which does not include retired workers, indicated that $18.6 \%$ of the economically active population in the IP area in the period 1985-

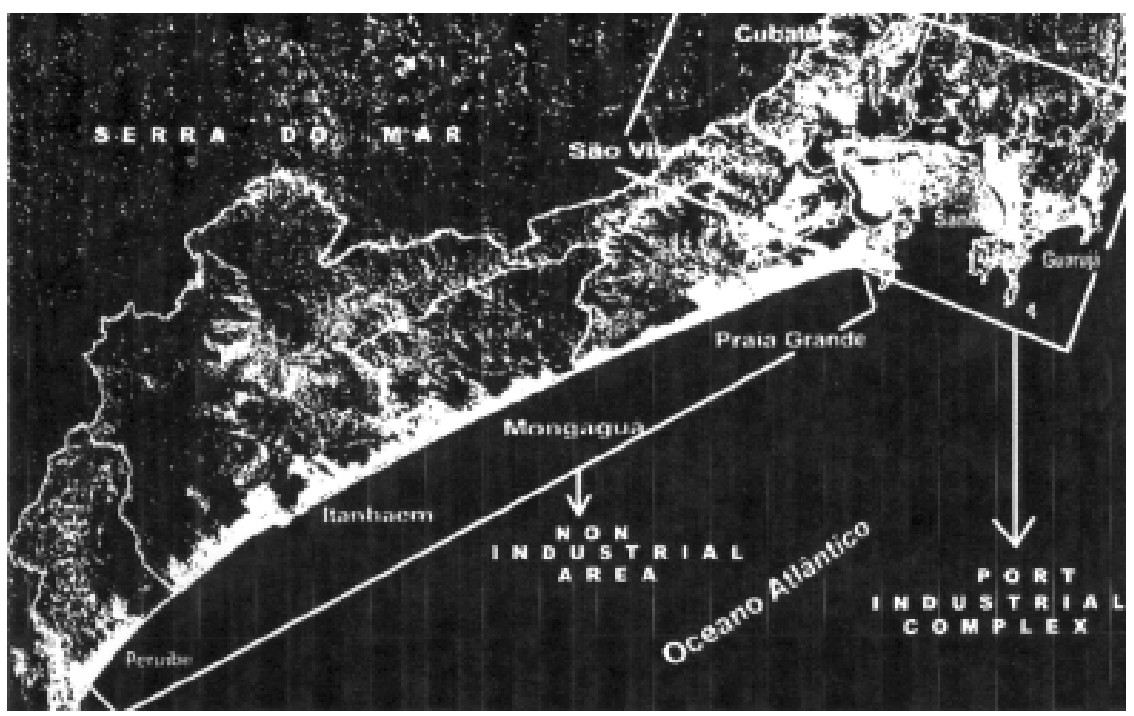

Figure 1 - Counties of Baixada Santista. Adapted from: Investment program in Baixada Santista. Sabesp. 1995. Government of the State of São Paulo.
1993, worked in industry, while in NIP the figure was only $7.9 \%$, concentrated mainly in small local companies.

1. Industrial-port area (IP) - The industries are concentrated in Cubatão, a small municipality of $148 \mathrm{~km}^{2}$. The first industries arose in 1912 (leather, rubber, paper, and cardboard). In the 1950s, oil refinery, petrochemical (styrene, carbon black, pentachlorophenol, carbon tetrachloride, methanol, formaldehyde, ethylene, polyethylene), and chloro-alkali industries were installed. Steel, fertilizer, and cement industries came in the 1960s. The people who work in the industrial plants mainly live in Santos and São Vicente, with the majority working in the steel and chemical industries ${ }^{12}$. Furthermore, this region has 3 ports: Santos (the biggest one in South America) and two others that are industrial, located in Cubatão where raw materials and final products, mainly chemical substances utilized in the industrial complex are handled. Only in 1965 in this region was the implementation of more effective measures of the industrial hygiene.
2. Mortality rates and ratios From registries from the State System of Data Analysis Foundation (SEADE) the estimated population and deaths that occurred in male residents above 10 years of age, in the industrial-port (IP) and non industrial-port (NIP) areas of Baixada Santista, were determined. In order to study the cancer mortality based on death certificates, 1105 deaths due to GC (ICD 151) and 690 due to CRC (ICD 153-154), from 1980 to 1993, were investigated.

Standardized mortality rates were calculated, age-adjusted by the world population in the 1960s, for residents in the IP and NIP areas, during the periods 1980-1993, 1980-1986 and 19871993. To compare the mortality between IP and NIP during all periods, the ratios among those standardized mortality rates were used. Statistical significance was set at the $95 \%$ confidence level. This methodology is the same as that used by International Agency for Research on Cancer (IARC) ${ }^{13}$.

\section{RESULTS}

The standardized mortality rates for BS during the period 1980-1993 were 25.9/100,000 for GC and 16.3/100,000 for CRC. In the case of GC, there was a statistically significant decrease, from 28.2 to $24.1 / 100,000$, with a ratio of 1.1 [95\% CI 1.0 - 1.3] from 1980 1986 to 1987-1993, while for CRC, the rates were similar: 16.4 and $16.2 /$ 100,000 respectively.

For CRC, the standardized mortality rates were significantly higher in the IP area for all periods, with ratio of 1.6 (CI $1.3-2.0$ ) for the total period (Table 2). Even when environmental hygiene measures were taken during the period 1987-1993, a significant

\footnotetext{
a The "Cancer and Work" project analyzes the morbidity-mortality of different kinds of cancer related to the manufacturing and work process, industry, occupation, and chemicals.

${ }^{\mathrm{b}}$ RAIS is a annual publication of the Labor Ministry that contains information about the economically active population.

c SEADE is a Governmental Institution of the State of São Paulo, which stores all demographic information of the state.
} 
excess in mortality occurred in the industrial-port area, with a ratio of 1.6 (CI 1.2 - 2.00).

For GC, there was no statistical difference between IP and NIP areas in all the periods compared (Table 3), even in reference to before the previously mentioned measures of prevention. However, in contrast to the case with $\mathrm{CCR}$, a significant overall reduction in mortality occurred in the BS region.

\section{DISCUSSION}

In Baixada Santista, GC, with a mortality rate of 25.9/100,000, was

Table 1 - Gastric and colorectal cancer mortalities in males, over 10 years of age, in Baixada Santista during the periods: 1980-1993, 1980-1986 and 1987-1993.

\begin{tabular}{|c|c|c|c|c|c|}
\hline \multirow{3}{*}{ SITES } & \multicolumn{3}{|c|}{ RATES $/ 100.000 *$} & \multirow{3}{*}{$\begin{array}{l}\text { RATIO } \\
\mathrm{a} / \mathrm{b}\end{array}$} & \multirow{3}{*}{$\mathrm{CI}^{* *}$} \\
\hline & \multirow{2}{*}{$\begin{array}{c}\text { TOTAL } \\
1980-1993\end{array}$} & \multicolumn{2}{|c|}{ PERIODS } & & \\
\hline & & 1980-1986 (a) & 1987-1993(b) & & \\
\hline Gastric Cancer & 25.9 & 28.2 & 24.1 & 1.1 & $1.0-1.3$ \\
\hline Colorectal Cancer & 16.3 & 16.4 & 16.2 & 1.0 & $0.8-1.1$ \\
\hline
\end{tabular}

* Standardized to the world population in the 1960s; ** 95\% confidence interval $(\mathrm{p}<0.05)$.

Table 2 - Comparison of colorectal cancer mortality* in males, in the industrialport (IP) and non-industrial-port (NIP) areas, in Baixada Santista, during the periods: 1980-1993, 1980-1986 and 1987-1993.

\begin{tabular}{|c|c|c|c|c|}
\hline \multirow[t]{2}{*}{ PERIODS } & \multicolumn{2}{|c|}{ BS } & \multirow{2}{*}{$\begin{array}{c}\text { RATIO } \\
\text { a / b }\end{array}$} & \multirow[t]{2}{*}{ CI** } \\
\hline & IP (a) & NIP (b) & & \\
\hline $1980-86$ & 17.5 & 10.4 & 1.6 & $1.2-2.2$ \\
\hline $1987-93$ & 17.4 & 10.8 & 1.6 & $1.2-2.0$ \\
\hline $1980-93$ & 17.4 & 10.6 & 1.6 & $1.3-2.0$ \\
\hline
\end{tabular}

* Standardized to the world population in the $1960 \mathrm{~s} ; * * 95 \%$ confidence interval.

Table 3 - Comparison of gastric cancer mortality* in males, in the industrial-port (IP) and non-industrial-port (NIP) areas, in Baixada Santista, during the periods: 1980-1993, 1980-1986 and 1987-1993.

\begin{tabular}{|c|c|c|c|c|}
\hline \multirow[t]{2}{*}{ PERIODS } & \multicolumn{2}{|c|}{ BS } & \multirow{2}{*}{$\begin{array}{c}\text { RATIO } \\
\text { a / b }\end{array}$} & \multirow[t]{2}{*}{$\mathrm{CI}^{* *}$} \\
\hline & IP (a) & NIP (b) & & \\
\hline $1980-86$ & 28.8 & 25.0 & 1.1 & $0.9-1.4$ \\
\hline $1987-93$ & 24.6 & 22.4 & 1.0 & $0.8-1.3$ \\
\hline $1980-93$ & 26.5 & 23.4 & 1.1 & $0.9-1.3$ \\
\hline
\end{tabular}

\footnotetext{
* Standardized to the world population in the $1960 \mathrm{~s} ; * * 95 \%$ confidence interval.
}

were found to be at risk: food industry, printing and publishing, skilled production and sheet metal, petroleum product trade, communication, finance, insurance, government, managers, administrators, executives, artists, entertainers and athletes.

In addition, in the petroleum, metallurgical, and chemical industries, many carcinogenic chemical substances such as aromatic polycyclic hydrocarbons, formaldehydes, phenoxyherbicides, and dioxins have been associated with $\mathrm{CRC}^{6,16-20}$.

A comparison between industrialized and non-industrialized areas of Baixada Santista showed a statistically significant higher CRC mortality during all periods (Table 2). According to the Governmental Institutions (CETESB) $)^{9,10}$ and Fundacentro ${ }^{21}$, most of the chemical substances mentioned above, as well as others, are present in Baixada Santista in the occupational and general environment of industrialport area, including raw materials, intermediate substances, final products, or wastes, such as aromatic hydrocarbons, formaldehydes, pentachlorophenol, carbon tetrachloride, and other chlorinated hydrocarbons, heavy metals (cadmium, nickel and chromium), nitrogenated compounds; sulfur dioxide, sulfur trioxide, fluorides, ammonia, sulfuric acid, carbon monoxide, cycloparaffins, nitrogen dioxide, coal, coke, and graphite materials.

Despite these findings, higher consumption of proteins and animal fat, the reduction of food with fiber contents, and sedentary life styles remain important as risk factors for CRC. In contrast, other factors are considered to be protectors, such as the habit of consumption of vegetables and fruit with high fiber content and physical activity ${ }^{22-25}$. Genetic mechanisms are also included among these etiologic factors $^{25,26}$. Thus, for CRC, a greater interaction between exogenous factors, endogenous mechanisms, and fre- 
quently, genetic factors seems to occur. All of those conditions and factors are present in Baixada Santista, an urban region. Therefore, an ecological study such as the current one is insufficient for understanding the role of each of them in our results. Consequently, it is necessary to conduct additional epidemiologic studies in order to better analyze these associations.

When analyzing the periods of 1980-1986 and 1987-1993, it was observed that the CRC mortality rates did not change with the time (Table 1).

Regarding CG in Baixada Santista, there was a tendency for a significant reduction in mortality, and this trend has been reported worldwide ${ }^{15,27-29}$. Howson et al. ${ }^{27}$, identified a decrease of GC mortality in the period from 1950 to 1979 in various developed countries, with a drop of between $65 \%$ and $73 \%$ in Scandinavia and the U.S.A., between $59 \%$ and $62 \%$ in Western Europe, 56\% in Australia, and between $45 \%$ and $41 \%$ in Japan, Ireland, and Italy. In North America from 1930 to 1980, there was a drop in mortality from 37.0 to $10.0 /$ 100,000 in males ${ }^{28}$.

The universal tendency towards reduction of GC mortality seems to be linked to the introduction of new alimentary habits, facilitated by the application of modern technology in the production, transport, and mainly in alimentation. The better preservation of foodstuffs as a consequence of refrigeration, especially for meat, fruit, and vegetables, has resulted in the reduc- tion of nitrites and salt content and an increase in the $\mathrm{C}, \mathrm{E}$, and $\mathrm{A}$ vitamin consumption and in the reduction of contamination risks ${ }^{4,5,7,27,28}$.

Cultural and technological patterns that change according to the socioeconomic conditions would explain this more precocious and differentiated mortality drop in the developed countries since 1930 in the U.S.A, 1950 in Japan, 1960 in England and Finland ${ }^{27}$, and from 1980 to 1993 in Baixada Santista, when such standards of living began to increase.

In Denmark in 1992, Lynge $^{30}$ noted the reduction of $\mathrm{GC}$ over the last 45 years and analyzed the contribution of socioeconomic conditions in this process. In her study analyzing the transition from an agricultural to an industrial society, she observed that the characteristic patterns of the cancer development, in general, reflect the social history.

Although no statistically significant differences were observed for the mortality from GC among the areas studied in the BS (Table 2), several studies have identified the association between GC and occupational industrial exposure. Blair et al. ${ }^{18}$, observed an increase in the relative risk of GC among workers exposed to fertilizers and pesticides, attributing it to the possible exposure to nitrosamines. Hanis et al., ${ }^{16}$ identified slightly increased relative risks in oil refinery workers. Siemiatycki et al. ${ }^{31}$, Simonato and Saracci ${ }^{17}$, and Weiland et al. ${ }^{32}$, reported studies demonstrating the increasing risks in other sectors and industrial occupations. Mirvish ${ }^{5}$ and IARC $^{33}$ recognized the association of GC with exposure to mineral dust and to coal. In a case-control study carried out by Gonzales et al. ${ }^{7}$ in 1991, the GC association was elevated by work in mines after about 20 years of exposure. However, we did not find a significant difference between the industrialized and non-industrialized area of Baixada Santista.

Therefore, in our study, the GC mortality seems to be more related to general characteristics of na urbanized population, enjoying modern living standards and technological advances, and not exposure to the environmental pollutants present in that region. On the other hand, the excess of CRC mortality in the industrialized area seems to result from the manufacturing processes and its characteristics in terms of multiple occupational risk factors related to the habits and lifestyle. For these reasons, epidemiologic studies, such as case-control studies, must be carried out to characterize and better define the role of occupational risks as well as life-style habits, socioeconomic conditions, and genetics in the causation of these types of cancers.

ACKNOWLEDGMENT: This study was supported in part by grants from CENEPI, Ministry of Health and we are grateful for the help received from the $E$. J. Zerbini Foundation.
MEDRADO-FARIA $\mathrm{M}$ de A e col. Mortalidade por cânceres gástrico e colorretal em uma área urbana-industrial do Brasil. Rev. Hosp. Clín. Fac. Med. S. Paulo 56(2):47-52, 2001.
Objetivo: Estudar a mortalidade por cânceres gástrico e colorretal na Baixada Santista, região Sudeste do Brasil, onde situa-se importante complexo urbano-industrial.
Método: Dos registros da Fundação Sistema Estadual de Análise de Dados (SEADE), obteve-se 1105 óbitos por câncer gástrico (CID 153-154) e 690 por câncer colorretal (CID 151), ocor- 
ridos em homens acima dos dez anos, residentes na Baixada Santista no período de 1980 a 1993, que encontramse distribuídos entre os quatro municípios vinculados ao complexo industrialportuário (área industrializada) e os quatro municípios situados fora dele (área não industrializada). Para cada câncer e para as áreas foram calculadas as taxas de mortalidade, padronizadas pela população mundial de 1960. Calculou-se então as razões entre essas taxas nos períodos de 1980-93, 1980-86 e 1987-93.

Resultados: As taxas de mortalidade para o câncer colorretal foram significantemente mais altas na área indus- trializada com razões de 1,6 [IC 1,22 2,29], 1,6 [IC 1,2 - 2,0] e 1,6 [IC 1,3 $2,0]$, respectivamente nos períodos de 1980-86, 1987-93 e 1980-93. O câncer gástrico não apresentou diferença entre as áreas industrializadas e não industrializadas, mas decresceu significantemente na Baixada Santista entre os períodos de 1980-86 e 1987-93.

Conclusões: $O$ excesso de mortalidade por câncer colorretal na área industrializada pode estar relacionado com a exposição a numerosos carcinogênicos orgânicos (hidrocarbonetos aromáticos e alifáticos clorados) e metais (cádmio, cromo e níquel) presen- tes na região. A diferença não significante para o câncer gástrico entre as duas áreas e o decréscimo nos últimos anos estaria refletindo predominantemente os avanços na qualidade de vida nas áreas urbanas. Esses resultados demandam a realização de estudos casocontrole para analisar as associações entre esses cânceres e os fatores ambientais (ocupacionais, urbano-industriais, hábitos, condições de vida e suscetibilidade genética).

DESCRITORES: Mortalidade por câncer. Epidemiologia do câncer. Câncer de estômago. Câncer colorretal.

\section{REFERENCES}

1. PARKIN DM, PISANI P \& FERLAY J - Estimates of the worldwide incidence of eighteen major cancers in 1985. Int J Cancer 1993; 54: 594-606.

2. INSTITUTO Nacional de Câncer (INCA) - Estimativa da incidência e mortalidade por câncer no Brasil. Ministério da Saúde. Coordenação de Programas de Controle de Câncer, Rio de Janeiro, 1995.

3. FONSECA LAM - Mortalidade por câncer no Estado de São Paulo: perfil atual, distribuição geográfica e tendências temporais. São Paulo; 1996. [Tese de doutorado. Faculdade de Saúde Pública da Universidade de São Paulo].

4. MACLURE, KM \& MACMAHON E - An epidemiologic perspective of environmental carcinogenesis. Epidemiol Rev 1980; 2: 19-48.

5. MIRVISH SS - The etiology of gastric cancer: intragastric nitrosamide formation and other theories. J Natl Cancer Inst 1983; 71(3): 629647.

6. BROWNSON RC, ZAHM SH, CHANG JC et al. - Occupational risk of colon cancer. Am J Epidemiol 1989; 130(4): 675-687.

7. GONZALEZ CA, SANZ M, MARCOS G et al. - Occupation and gastric cancer in Spain. Scand J Work Environ Health 1991; 17:240-7.

8. FRUMKIN H - Carcinogens. In: LEVY BS \& WEGMAN DH Occupational Health: recognizing and preventive work-related disease. Boston, Little, 1995. p.287-304.

9. COMPANHIA DE TECNOLOGIA DE SANEAMENTO AMBIENTAL (CETESB) - Resíduos sólidos industriais na bacia do Rio Cubatão. Secretaria do Meio Ambiente do Estado de São Paulo. 1980 .
10.COMPANHIA DE TECNOLOGIA DE SANEAMENTO AMBIENTAL (CETESB) Avaliação de poluentes atmosféricos de origem industrial, na região de Cubatão - subsídios para uma política de ação. São Paulo, CETESB/DEAR, novembro, 98 p. 1980.

11. EMPLASA - Por Dentro da Região Metropolitana da Baixada Santista. Secretaria da Fazenda do Estado de São Paulo. São Paulo, 1996.

12. GOLDSTEIN L - A industrialização da Baixada Santista. Estudo de um Centro Industrial Satélite. São Paulo, 1972. [Tese de doutorado. Universidade de São Paulo].

13. SMITH PG - Comparison between registries age-standardized rates. Cancer incidence in Five Continents. Lyon, France: International Agency for Research on Cancer, 1987. IARC Sci. v. 5, pub. nº 88.

14. MEDRADO-FARIA MA, ALMEIDA JWR \& ZANETTA DMT Mortalidade por câncer na Baixada Santista. Complexo industrial e demais municípios, período de 1980-1996. Relatório para o Centro Nacional de Epidemilogia (CENEPI/Ministério da Saúde). Brasil. 1997.

15. PARKER SL, TONG T, BOLDEN S et al. - Cancer Statistics, 1996. Ca Cancer J Clin 1996; 65: 5-27.

16. HANIS NM, STRAVAKY KM \& FOWLER JL - Cancer mortality in oil refinery workers. J Occup Med 1979; 21 (3): 167-174.

17. SIMONATO L \& SARACCI R - Cancer occupational. In: Encyclopaedia of Occupational Health and Safety, $3^{n}$ edition. Geneva, International Labour Office, 1983. v.1, p.369-375.

18. BLAIR A, WALRATH J \& ROGOT E - Mortality patterns among US veterans by occupation. I Cancer. J Natl Cancer Inst 1985; 75: 1039. 
19. SARACCI R, KOGEVINAS M, BERTAZZI PA et al. - Cancer mortality in workers exposed to chlorophenoxy herbicides and chlorophenols. Lancet 1991; 338: 1027-32.

20. MARSH GM, STONE RA, ESMEN NA et al. - Mortality among chemical workers in a factory where formaldehyde was used. Occup Environ Med 1996; 53:613-627.

21. FUNDACENTRO - Estudo das condições de Higiene Industrial da Companhia Siderúrgica Paulista (Cosipa). São Paulo. 1980.

22. ARMSTRONG B \& DOLL R - Environmental factors and cancer incidence and mortality in different countries, with special reference to dietary practices. Int J Cancer 1975; 15: 617-631.

23. GERHARDSSON M, NORELL SE, KIVIRANTA H et al. - Sedentary jobs and colon cancer. Am J Epidemiol 1986; 123(5): 775-780.

24. MARTÍNEZ ME, MACPHERSON RS, ANNEGERS JF et al. Association of diet and colorectal adenomatous polyps: dietary fiber, calcium, and total fat. Epidemiology 1996; 7(3): 264-68.

25. POTTER JD - Nutrition and colorectal cancer. Cancer Causes Control 1996; 7: 127-146.

26. CALDAS C \& PONDER BAJ - Cancer genes and molecular oncology in the clinic. Lancet, 1997; 349(suppl II): 16-18.
27. HOWSON CP, HIYAMAT \& WYNDER EL - The decline in gastric cancer: epidemiology of an unplanned triumph. Epidemiol Rev 1986; 8:1-26.

28. FUCHS CS \& MAYER RJ - Gastric carcinoma. N Engl J Med 1995; 333(1): $32-41$.

29. AZEVEDO G \& MENDONÇA S - Evolução da mortalidade por câncer de estômago no Estado do Rio de Janeiro: uma comparação entre a região metropolitana e o interior no período de 1979 a 1986. Cad Saúde Públ 1997; 13 (suppl 1): 79-84.

30. LYNGE E - Cancer morbidity by occupation. Scand J Work Environ Health 1992; 18 (suppl 1): 50-56.

31. SIEMIATYCKI J, RICHARDSON L, GÉRIN M et al. - Associations between several sites of cancer and nine organic dusts: results from na hypothesis-generating case-control study in Montreal, 19791983. Am J Epidemiol 1986; 123(2):235-24.

32. WEILAND SK, MUNDT KA, KEIL U et al. - Cancer mortality among workers in the German rubber industry: 1981-1991. Occup Environ Med 1996; 553: 289-298.

33. INTERNATIONAL Agency for Research on Cancer - IARC monographs on the evaluation of the carcinogenic risk of chemicals to humans. Lyon, France, 1982.

Received for publication on October 26, 2000 